\title{
Wild Objectification: Social Work As Object
}

\section{Summary}

The paper is about objectification in and of social work. Drawing on a decade-long cooperation with a Copenhagen social workers network focused in the organization Wild Learning, and starting from an Internet essay this organization has provided, the problems with objectifying social work are discussed. Viewed as basically a wholistic subjectification, social work cannot easily be endowed with objectivity in the form of scientific standards, and the objects representing it are often like novels, uniqueness mass-produced; they can be said to ideologically confirm rather than scientifically model its activities and communities. The approach to objectification must dig a level deeper. It is considered how objectifications in social work - and the Internet essay is taken as example - can be approached critically as ideological objectifications and at the same time, in the cultural-historical tradition, as prototypes with some scope of relevance.

\section{“18.5.2002}

\section{About hash - no 3 \\ Experience and opinions concerning hash Girl, 16 years}

The first time I tried to smoke hash myself, I was 12. The first couple of times I smoked, I was with friends who were used to smoking. At first, I actually didn't like being stoned, so I don't know why I went on. Today, I wish
I'd never started, because now I like it, and I smoke every day. I began smoking daily when I'd just turned 16. It started in the summer holiday, when we would hang out with a group of boys who smoked daily. Not that I blame them; only it became ordinary to smoke daily when one was with them. I don't go out with those boys anymore, but I still smoke daily. In some ways I'd like to stop smoking, in other ways I wouldn't. I'd like to stop because I feel it makes me stupid and forgetful. The reason why I won't stop is that I like to smoke and be stoned.

Girl 16 years"

These words are available to the (Danish-reading) global public at the website of the Copenhagen social work development network Wild Learning ${ }^{1}$. There are a handful of reasons to quote them here, at the opening of a paper about objectification in social work.

First, the organizing of the writing and reading is directly part of the performance of a particular local instance of social work. The words anyone can see on his screen, then, are

1 16.12.2003: http://www.vildelaereprocesser.dk/kronik/ kroniktekst.php3?id=95 - translated from the Danish by $\mathrm{MN}$ 
in a certain way a direct sample, congealed as an objectification of that social work.

Second, even as a form of objectification, it is quite far from any "objectivity" in the sense of authorized truth or method - it is the bold statement of a distinctively subjective and quite heterogeneous experience and opinion on the part of the girl, and the social workers have only a personal experience as their background for arranging it, just as they have no idea where it will lead them.

Third, it deals with diversity in the fashionable form of merely displaying it, recognizing what could have also been tabooed or stigmatized as deviant, accepting it as part of this multiple world we're in, and thus leaving completely open the question of whether the deviant should be normalized, or, rather, normativity should be defied, or indeed, what might be an alternative to this predicament altogether.

Fourth, this obvious lack of commitment provides an interesting tension to the discipline, not only of traditional social work, of drug treatment programs, or of parents and other authorities who attempt to sanction hash as illegal, but also that of the website itself as an ideological form, and of the subjectivities and the communities it endorses.

Fifth, it matches the discipline of practice research as it is directly a reference which I've agreed with my social worker partners in Wild Learning to work on transforming.

These reasons make sense because this paper is about the objectification of social work as unique but prototypical practices of some relevance.

I shall return to the website, the quote, and those points about it, below. But first, I need to introduce Wild Learning in more general terms.

\section{Wild Learning}

For more than a decade, the social workers of the network which currently gathers around the organization called Wild Learning have been recognized as a kind of bare-foot development agents in the fields of socially excluded and drug misusing youth in Copenhagen. Like so many other contemporary state authorities, Copenhagen City attempt to meet the challenge of double social exclusion - from 'normal' school, employment etc. as well as from the traditional institutions of social work - with a two-pronged approach to development: a mobilization of users and community organizers as the allies of central officials both attacking narrow-minded professionalism.

Wild Learning is a through-and-through ad hoc, network organization that grows at times and places of trouble in specific intiatives negotiated between officials at different levels (sometimes also politicians), professionals of different institutions, youngsters - and as overall mediators, the Wild Learning social workers. Its 'members' have varied, but comparatively low, levels of formal education, and a substantial number are themselves former 'street kids'. Memberships, activities and carrieers emerge organically from judgments and negotiations about unique individuals in unique situations in relation to unique project ideas. One qualifies by participating, taking responsibility, and making things work.

Nearly all this time, I and a few colleagues and students have been engaged in a mixture of ethnography and action research partnership with those social workers and some officials (Mørck, 2000; Mørck, 2003; Nissen, 1997; Nissen, 1998b; Nissen, 1998a; Nissen \& Pedersen, 2000; Nissen, 2002b; Nissen, 2002a; Nissen, 2004a; Nissen, 2004b; Nissen, 1999a; Nissen, 1999b; Nissen, 2000; Nissen, in press), treating the network as a kind of proto-typical social practice that embodies, creates, and/or tackles issues of subject-formation, marginalization, learning, and method in social work. In several series of tape-recorded interviews and group discussions (22 and 27, respectively, since 1999), social workers were prompted 
to explain or narrate their ways of working (sometimes focused on special themes such as power, drugs, or trajectories of learning); we have participated in a 3-years sequence of monthly 3-4 hours network meetings often dedicated to presenting local projects, describing ways of working, and discussing dilemmas and possible solutions, and recorded the discussions in field-notes; a large body of written material has been collected, primarily pamphlets, internet texts, internal notes, project blueprints, and other "collective" materials (rarely files on individual youngsters). All the while, we as researchers have regularly fed back analyses both in informal contacts, in the course of interviews etc., in structured oral form (e.g. systematic presentations at the network meetings), and in writing of various kinds, including, and increasingly significant, internet texts at the Wild Learning website.

When asked to explain by what methods these often young and unskilled persons seem able to solve problems in the face of which many a well-educated and experienced social worker or therapist have surrendered, the very concreteness and particularity of the organization and its members is often taken to be the crucial pedagogical resource. It is not a question of being the right kind of person, but of being the right person; no method is right - it all depends on the situation, so the right situation has to be created; the turning points are accomplished when everything is put at stake and rules are broken; and it is when the youngster understands himself to be recognized as unique that he can break the patterns of social exclusion.

Thus, anti-method is a suitable name for the method (Nissen, 2004a). Now, it is tempting, perhaps, to take this paradoxical state of affairs as indeed something unequaled, in the sense of saying that these social workers have discovered a hidden truth of a superior method that may now (with the humble assistance of researchers such as myself) be spread as good news to the profession. The trick, then, and the reason why it has been hidden, is the very paradox: who would look for anti-method in the search of method? But soon, with the Outlines on the streets, its very uniqueness will be replicated by "wild" social workers in every alley and burg, from Kajanin to Capetown.

Or, conversely, it may be tempting to use the pervasive singularity as the good reason for refusing to take the experience and the apparent succes of Wild Learning into account: it all results from a lucky combination of unique features of an exceptional situation. Indeed, understanding the Wild Learning experience does require that one looks to the specifics, not just of this group of people, but also of a decade of turbulent political and administrative reorganizations, of the hard work, the struggles, and the eventual success of particular groups of officials, of the adolescence of the first generation of children of immigrants in one of Copenhagen's poor districts, in a time of recession followed by post-industrial exclusion of the unskilled, and in a climate of increasing political polarization, of the reorientation of certain political groups etc.

Still, my thesis is that what we are dealing with is neither just universal nor just particular, but a problematic of some generality which makes it sufficiently interesting to reflect.

\section{Subject-formation in general education and social work}

To make this point, let us first, for a moment, challenge it by diving into another very unique situation, quite remote in time, space and overall cultural context. One of the few classic textbooks on youth work that have circulated among some of the social workers in Wild Learning is Anton Makarenko's The Road to Life - an Epic of Education, from 1935 (Makarenko, 2002). The book is a novel - even sometimes referred to as a "pedagogical poem" - that reports the establishment, de- 
velopment, and subsequent dissolution of a colony for street kids in the Ukraine in the 1920's. Makarenko is the leader of the colony, the main protagonist, the reflexive narrator, and the author. The fundamental approach is anti-methodical. The turning point which founds the colony is when Makarenko, driven to despair, forgets all about rules and regulations and first exposes himself, taking up a conflict for real, physically attacking a boy, and then goes on to organize the physical labour that is directly necessary for survival. Even while fighting famine, violent crime, and kulak exploitation, the worst enemies are always the pedagogical professionals. A true revolutionary humanism expresses itself, according to Makarenko, in stepping out of the false world of abstract theory and method, and engaging with real life issues. It is in the collectivity of labour and conflict that the new man of the new society is formed. Makarenko describes himself as allied with the boys and with the upcoming leaders of the new society, against petty bourgeoisie in the form of kulaks and in the form of pedagogues. One can hardly imagine a more direct and tangible interconnection between the formation of the individual, the local community, and the new society - of the new state, the borders of which barely secured.

But why is it, exactly, that Makarenko's poetic narrative of events so far from the Wild Learning experience can become somehow a useful reference? Perhaps, it may be speculated, it is because his is an early account of an "anti-method" which is much later to become fashionable? I would suggest, rather, that it is because that "anti-method" is itself a deep and age-old aspect of pedagogical and social work. Allow me a short genealogical detour.

In fact, even though Makarenko hates pedagogues, his epic can be read as quite representative of a long pedagogical tradition that can be characterized as a discourse on formation or general education (Danish: "Dan- nelse"; German "Bildung") which emerged much earlier with such writers as Rousseau and Humboldt. According to Arnd Hofmeisters genealogy (Hofmeister, 1998), already two centuries ago the problem of the formation of subjects was developed, as the problem of the self-determined and the general, the crosscontextual competences that were demanded of the citizens of a differentiated society. Characteristic of this Bildungs-discourse was and is the idea of a positive relationship between human nature as general potentials and the needs of a new society (in a new state), a relation which realizes itself in the citizen's mastering, but also, and not least, superceding and even breaking the old rules and knowledges and assuming responsibility for the potentials of the "real", that which lies beyond tradition, beyond discourse, the virgin land to be cultivated anew ${ }^{2}$.

In the field of social work, we can also find reasons for anti-methodical tendencies. Viewed genealogically (Cruikshank, 1999; Donzelot, 1979; Philp, 1979; Rose, 1999; Stenson, 1993; Sunesson, 1981), the "social" refers to society as a general object of problematization. In the framework of a welfare state generally characterized by a comprehensive intervention by the state into family and civil society, social work becomes a realization of the humanity of both the individual and society. According to Mark

2 Incidentally, these points are easily recognized in Wild Learning if one views the way staff learning is conceived. Probably the best interpretation of the pedagogical ethos of Wild Learning is one formulated from a situated learning approach (Lave \& Wenger, 1991), to which the cross-contextuality, the self-determination, and the deep immanence of learning in practical changes, are central. Such an interpretation is done by my research colleague in Wild Learning, Line Lerche Mørck (Mørck, 2000; Mørck, 2003). Of course, both Wild Learning, Lave, Wenger, and Mørck stress, in addition, the social aspect and the formation of communities much more directly than is typical of learning practices and theories - thereby approaching a social work discourse. 
Philp, social work arises with the recognition of the working class as the dealing with the residual lumpenproletariat that now represented the social problem, as the attempt to mediate between society and the socially excluded by three operations: the formation of singular subjects, the integration of objective features into this subjectivity, and the speaking on behalf of it. Social work, thus, is the formation of subjects, in connection with the formation of a welfare state and its various constituent communities. Philp's main point is that this makes it hard to objectify in a scientific form of knowledge: social work becomes distinctive precisely by negating the objectivity of its object.

Social work shares this dilemma resulting from the positing subject-formation as its object with Bildung, general education. But social work's emphasis on the social, on solving social problems, or even solving the social problem, at least when this is substantiated in a political process, in a welfare state, widens the scope of concerns.

It means, for one thing, that the issue of everyday life enters into the field of social work in the broader notion of community rather than merely in the form of "conduct of life" that appears in educational thinking. Without ever realizing its own aspirations of a genuine social engineering, social work's formative effort again and again steps from the individual to the level of some social entity, the vagueness of which is characteristic of the concept of community.

And, for another, it means that social work adds the 'negative generality' of health to the 'positive generality' of formation/education. Social work is directed at solving social problems and includes therapeutic discourse as well as educational. By virtue of its very generality, social work can put together in one field medicine and education; but social work only remains itself so long as it does not specialize in either: so long as it operates the subjectifi- cation of welfare state citizens and communities, rather than cures diseases or teaches qualifications.

These features add more reasons to be sceptical of method and objectivity: the reciprocity of formation between individual, community, and state means that revising and setting, rather than applying, standards becomes a qualifying feature in itself. And to specialize in spanning the whole range of sciences and professions directed at human life means specializing in vagueness - when knowledge and intervention becomes specific, it is no longer really social work. Thus, on the one hand, social work tends toward an idealistic humanism that remains reluctant to identify with its own objectifying realizations. On the other hand, the normative dimension intrinsic to social work as a form of practice tends to appear profanely ideological to the point of "totalitarianism" because it deals with social totalities - no fixed standards (such as those norms derived from biological functioning or from specific knowledge and skills) can defend against (charges of) ideology or moralism.

This wholistic and necessarily ideological nature of social work is precisely apparent in Makarenko. He organizes shooling and appreciates specific knowledges, but he devotes attention to the overall attitudes, ways of life, and responsibility of the children. He deals with specific problems and malfunctions, but always views them as steps in the development of his colony. And the way his colony is directly part of building the new society, writing its mythology, appointing its heroes and foes, and demanding its support, is apparent. His crusade against pedagogues is always against the superstitions of the old society and the attempt to speak for the human beings of the new.

The fact that Makarenko's narrative is situated so obviously at a time and a place where a "new society" meant a "new state" lets us notice Mark Philp's Althusserian backdrop. 
In Althusser's theory of “ideological state apparatuses"(Althusser, 1994), subjectification is not only the exercise of a power that leads to a conscientious or "ethical" self, but also an interpellation, a forming of a unique subjectivity in an intersubjective relation of identification with a capital S "Subject": the state apparatus, alienated into the shape of God. I suggest, following (Højrup, 2003a), that we view the state less as an "apparatus" and more as a community, a singular unit of living culture which inheres subjectivity as it establishes itself vis-a-vis other states and its subject participants, and as it is ideologically defined as an ideal form which is always contested and imperfectly realized. It is from this vantage point, then, that interpellation becomes more of a mutual process where subjectification is always also the reconstitution of community. This idea can be put to use in an approach to the welfare state as the form of state which not only intervenes massively in civil society and families, but does this in ways which are both productive and self-transforming - by not only regulating, but also comprehensively building the institutions which become the organized venues of communal life, such as kindergartens, schools etc. Social problems, under such conditions, can always, at least potentially, be turned back against the state as the demand for an expansive transformation of the system of institutions.

In Wild Learning, this interpretation of social work is also feasible, even if surely what is meant by the building of a new society and a new state is, viewed as overall totality, quite vague, since in today's political climate, the only clear vision of a reformed welfare state is the monster of its neoliberal disintegration. If we do accept that the constitutive bond must be more or less open at one end (at least) it is not difficult to view Wild Learning as something of an "ideological state apparatus". Subjectification and humanistic wholism are apparent, and the mutuality of formation of subjects and communities is present in the practiced idea that reorganization of social work institutions and building of networks is itself a crucial form of social work. This is not only because flexibility allows for user orientation etc., but, more crucially, as we shall see below, because the objectification in cultural objects that define such fleeting lower-level communities is a vital form of cultural pedagogy.

There is one dimension, though, in which the ideological character of Wild Learning even at the level of overall social policy is quite distinct. This is the discussion of legal versus social approaches to the criminal young. The past ten years have been a period of legal tightenings often connected with the rise of xenophobia in Denmark. Both the former 'third way' social-democrat and the new liberal government have conducted a policy of increasing incarceration to demonstrate resolve against drugs- or violence-related crimes of immigrant boys. The Wild Learning network have been quite clear in standing up against xenophobia and law-and-order rhetorics, and this is obviously connected with the ways projects and communities define themselves - even at the level of the City: "the Copenhagen way" is widely known for its emphasis on a street-level cooperation which is able to recruit not only street kids, but also muslim as well as radical socialist constituencies.

Facing the issue of crime, it is perhaps less ordinary that Wild Learning have, like Makarenko, departed from social work's traditonal tendency to pretend an absence of power. As Philp describes, social work is born in distinction from objectification of the outcast through direct exertion of power, like education and cure leaving power outside the door as a hidden premise. But the general or wholistic nature of social work means that this absense or invisibility of power is never really institutionalized like in therapy or schooling. At certain points, the ways in which social work is itself power come to the surface of the dis- 
course. Operating the bifurcations (Cohen, 1985) between subjects and non-subjects, social work is often directly normative even in the strong "totalitarian" sense of sanctioning deviance and marginalization, and this cannot be consistently disacknowledged. Social work is haunted, as it were, by the spectre of power; and the most common reaction to it is a critical rejection that is at once self-defining and self-denying.

One of the points of resurfacing of power is the street level. Here, a cooperative social approach is quite distinct from a sovereign or disciplinary power, but it also still does face the challenge of individuals' or gang's informal power, of the networks of power relations that lie beneath what is effectively and formally sanctioned by the institutions of legal power and of welfare state provisions. Thus, it must deal with the problem of ,social order" in its undifferentiated germ cell shape. To an extent, the social workers in the Wild Learning network have taken up that prototype as a challenge to social work's idealistic self-image.

In the case of drugs, Wild Learning, and Copenhagen City in general, represent an attempt to steer clear of both war-on-drugs and simple harm reduction policies. This is evidenced in the above quoted website text which exemplifies a refusal to demonize the drug user, but without, on the other hand, casting the drug user as a sensible and pragmatic risk calculator. Again here, the approach operates the border-line - it places itself in-between taking the subject for granted and denying it.

But before I discuss the website more closely, I need to discuss the implications of this discussion on social work anti-method and objectivity.

\section{Objectivity}

Obviously, any theoretical reflection of social work needs to transcend the dichotomy of subject and object in terms of which one precludes the other. Objectivity is something which is done. And subjectification itself results from the dialectics of objectification of the subject and the subject's overcoming of that objectification in a reconstituted participation (Nissen, 2004a; Nissen, 2004b). But the implications can be confusing.

Both therapy and scooling can be viewed in abstraction from the theme of subjectification, as the cure of specific malfunctions in organisms, and the reproduction of specific qualifications, respectively. That abstraction misses the point, so to speak, in terms of what matters in general to health and learning. But it can be argued that this abstraction from the essential is precisely the key to how subjectification works in these institutions. Health and learning becomes the responsibility of the subject because the practices are organized around a boundary objectivity derived from biology and science in the shape of pathology and didactics. The concept of a 'boundary objectivity', here, is developed from Star's concept of 'boundary object' (Bowker \& Star, 1999) to mean an objectivity established with a boundary object, an object that translates between social worlds by holding meanings intrinsic to each. One example is the "disease" that translates between medical practice and illness in everyday life and which thus may provide a boundary objectivity to the disciplinary aspects of health care.

If social work, by contrast, remains the general form where subjectification is directly appearing "in itself”, its objectivity becomes its temporary self-negation: objectification always seems to lead away from its essential or "authentic" realization, to bring about either a relapse into boundary objectivities or a return to the de-subjectifying objectifications of power.

One may fear, at this point, that all there is left for social work as such, "authentic" social work, are fleeting glimpses of particular subjectivities. But in fact, this is where particular objectifications in and of unique situations 
such as those of Makarenko or of Wild Learning become important. Both built unique, but also fairly strong and lasting communities; and to both, representational or epistemological artifacts played a significant role. Makarenko's book is a novel that discribes a unique situation and has been printed in thousands of copies in many languages. The Wild Learning network, as part of which alone our 16-years old hash-smoking girl becomes understandable, is equally unique, and the girl's text is equally multiplied onto potentially millions of computer screens.

Both objects, then, represent the double face of what Paul Willis (2000) calls the quasimodo cultural commodity, the combination of immediate usefulness and fetichism. It is implied that social work's failure to establish objectivity also allows market-like forms of objectification and distribution to be substituted for elitism and professional assymmetry, 'teaching' etc.

In both cases, the idea of objectification of social work should direct our attention, not to whether it represents practice truthfully, or whether the practices it represents are truly effective, but, more fundamentally, to how objects are produced, distributed, and used by communities, and not least, how they may be "representative" in the more pragmatic "diplomatic" sense that they contribute symbolically to constituting communities and participants.

Indeed, when rationalist aspirations are discarded - often on a firm empirical basis (Goffman, 1961; Sunesson, 1981) - the next logical step is to regard the objectifications which "ought to have been" representational in the epistemological sense of reflections, as rituals. For instance, the Danish sociologist DahlerLarsen (Dahler-Larsen, 2000) found that the recent boom in evaluations in the public sector could not be explained in a rationalist way, since decision makers are unlikely to actually follow recommandations or even take findings and analyses into account. Instead, he finds that organizations increasingly define themselves in terms of quality management, self-scrutiny, targeted intervention etc. Thus, the evaluations are rituals which literally make the sense with which the organizations and its participants understand themselves, even if they do not make sense in terms of what they say they do.

In a framework of critical psychology, activity theory, or, broadly speaking, the epistemology of practice derived from dialectical Marxism, the ontological question does not rule out the pragmatic. The making of sense does not preclude the production of meaning, and we don't necessarily, as did Goffman and his social constructionist descendants, have to bracket ontology in order to analyse symbolic interaction. More specifically, the problem of the object, and the objectivity of social work, remain relevant to how social work subjectifies, no matter with how many "laminations" it is "framed" (Goffman, 1986). Let us approach, then, the problem of our hash-smoking Internet girl as an artifact, as a cultural form of "the ideal" (Ilyenkov, 1977b) that is produced, performed and distributed in social practice, but which is that, precisely, because it holds real powers in a real world.

\section{The "hash-smoking Internet girl, 16 years", as object}

The girl is real. Not only does the girl who wrote the text exist, but the casting of her is a very real process, and her character and the stage on which she performs are artifacts that have real effects.

She is even staged as 'real', meaning that the whole idea of this, from one angle, is to demonstrate a rigorous realism in presenting the girl as she is, in all her problematic indecisiveness. This is presented as the naked truth of an intoxicated autobiography (Valverde, 2002; see also Plant, 1999) the message is that even if we may not like it, deal with it we must.

Deal with it, that is, not as we would have 
dealt with samples of some disorder in a texbook or lecture in psychiatry. When a psychiatric patient is used to display the tissue of disease, what is problematic is that she is reduced to a non-subject, to the mere object of medicine, as contrasted to our humanistic assumption that behind it is hidden a suffering subject. The corresponding Internet text format would probably be if the girl's text were surrounded by expert interpretations that point to signs in the text of dependency or madness or of the effects of the drug on the brain.

That tradition of objectifying social problems as samples of human tissue may appear obsolete. After all, are not indeed drug addicts as well as psychiatric patients today recognized as autonomous and responsible citizens who are to perform users' choices and engage in respectful dialogue and must be supported in the conduct of their everyday life? But in fact, in a way, at least, that old tradition rather thrives from the ascent of its opposite. The contemporary version of a "sample", in this case, would probably objectify the girl's disease and at the same time subjectify her as responsible for dealing with it. Thus, in the current Danish discussions around how to deal with hashsmoking, the wholistic social approach is opposed by a revival of drug counselling that focuses specifically on misuse, and in particular, misuse of hash. One popular form uses the technique of showing groups of youngsters graphs depicting how the level of $\mathrm{THC}^{3}$ in their brain only very slowly recedes, to explain how they feel and persuade them to interprete impatience with treatment as a well-described withdrawal symptom (Lundqvist \& Ericsson, 1999).

Here, instead, the girl's text is placed without comment in a journalistic category of serially ordered "essays", as the third out of five

3 Tetra-hydro-cannabinole, the active chemical agent in hash. hash-smoking girls, but among texts written by social workers, researchers, and officials (all of whom are offered assistance with the writing process by Wild Learning's journalist).

The troubling feature about this display of diversity is precisely its unproblematized subjectivity. As such, it reminds us of the kind of freak shows that swarm the media in the form of various social documentaries, the so-called "social pornography". Like with pornography proper, what triggers our compassion, or repulsion, or both, is that we can identify directly. Direct identification recognizes subjectivity, but manipulates it with the form of its mass media objectification to be static, immediate and naturalized (a point which was already made by Bertolt Brecht (1971). It is not only shockingly stripped, but also secretly seductive.

Thus, the reader may never even suspect that after all, the problems which the girl addresses are actually very traditional and most likely defined by the social workers! If we add material from the other 4 girls writing on hash on the same site and date, we have the following catalogue of themes: dependency; withdrawal; hash psychosis, memory loss and other side effects; relations between drug taking, drug debut and peer groups; the stepping-stone-hypothesis (i.e. does hash smoking lead on to worse drugs?); the effect on school performance. Such objects appear to be the natural environment of a hash-smoking "Girl, 16 years". Not exactly surprising to anyone already dressed in the white cloaks of health promotion and speaking its language.

Or the reader will be so fascinated with the documentary, honest naked truth format that she fails to reflect the fact that precisely the uncommitted double talk - the story-line of "I wish I'd never started, because now I like it" - is actually almost prototypical of drug prevention discourse, naturalizing the way each person is left alone with the ultimate paradoxes of self-control.

In short, the objectification of subjectivity 
realizes an ideological recognition. Bearing in mind how ideological recognition may be the core of social work, for better and for worse, we might look at bit more closely at the workings of this ideology, not only in the light of general discussions on themes (objects) such as drug use, but also in terms of the particular community, persons etc.

\section{Interpellation and critique}

This, then, is the profiling of Wild Learning as a state-of-the-art drugs project and the statement of a policy. This is one of the ways Wild Learning co-constructs the City's approach to drugs and to wild youngsters. And, if Wild Learning is right in the assumption that such policy statements can stand the frequent trials of strength that appear when the social problem of drug-taking youngsters becomes a matter for media, politicians and top officials, then the girl, with her text - and the text, with its girl - is directly participating in reproducing the conditions of a powerful community.

Discussions on issues of drug use in the small group of young girls and social workers ${ }^{4}$ have suddenly been turned from the inconsequential private as-if space of opinions and questions into public statements that matter. The same school-essay-like feature that I criticized above, the way the girl is interpellated to assume the ideological subject-position of a "hash-smoking 16-years-old" by writing about what the social workers ask of her - this is also, paradoxically, what takes it out of the chimerical pedagogical sphere and into the real life of the politics of Wild Learning that uses the Internet to recruit and align relevant powers. This way, the girl's participatory relation

4 The girls are anonymous and should remain so; but being a member of the Wild Learning network, I am able to guess in gross terms where they are situated to Wild Learning is objectified in the sense of becoming real.

From this point, a logic of substantialization might unfold. The author position of a self-determined and realistic girl is, as I hope I have shown, taken in itself, very superficial. By just writing anonymously and not giving very much of herself, she is profiling Wild Learning and at the same time reproducing the common sense of the social work landscape which Wild Learning is part of.

But let us make the realistic assumption that this was merely a first step. Embedded, as it is, in myriads of intertwined collectivities and activities, I have no way of guessing in which directions and with which artifacts the next steps will lead. But assuming, for the sake of the argument (although this assumption is much less realistic), that the nexts steps will include another Internet essay on hash-smoking, we can reasonably ask: Will it be one of the prevailing repentence narratives with which youngsters are typecasted to warn their younger peers in the spirit of a marginalizing normativity hidden behind a mask of identification? Or will it turn around and work to include more of herself and more of her friends by forcing the Wild Learning website to contain their youth subculture and even their good reasons for smoking hash?

The point is that both ways will change the policy statement of Wild Learning. Substantializing the interpellation as social work means realizing its mutuality. If the girl, from the point zero we are witnessing, is formed in a process where she will have to revise her uncommitted and naughty, yet compliant school-girl attitude, then Wild Learning, too, will be formed in a critique of the ideology which is displayed on the Internet. This way, the ideal features of Wild Learning as prototypical welfare state social work in the above circumscribed sense might be themselves substantialized - or is it maybe the idea of Wild Learning as prototypical of the way the welfare state is unknowingly dete- 
riorating into neoliberalism? Which will be the case we do not know yet.

The point is also that research plays a part in this critical process. This very analysis realizes a critique that is not only objectified here, but also in an essay I've written at the same website. The leader of Wild Learning asked me to comment on the hash-smoking girls' texts because he wasn't sure about their implications and wanted a critical input with which to reflect the organization's development. I tried to demonstrate the constructed and framed nature of the girls' truths and then provide an interpretation of them as instances of the social work of a democratized welfare state ${ }^{5}$.

\section{Research as critical objectification of prototypical practices}

The notion of critique as objectification, of course, is no news to a research community. The objective is that which objects, says Bruno Latour, or, in other words, that which resists trials of strength. Or, in the words of Popper, that which is open to, but as yet resists, falsification. But in this case, we are not sanctioning some universal objectivity. The truths we are dealing with are 'small' and ethical, as Valverde recommends us as the proper approach to intoxicated autobiographies (Valverde, 2002), but they nevertheless carry objectivity. Even

5 See (15.12.2003): http://www.vildelaereprocesser.dk/ kronik/kroniktekst.php3?id=103 and http://www.vildelaereprocesser.dk/kronik/kroniktekst.php3?id=114

6 Isabelle Stengers makes a similar point, using an example about knowledges on drug use, under the heading of a democratization of sciences (Stengers, 1999). With her Latourian roots she acknowledges that universality is problematized with democratization; but does she know also that she intervenes in the drugs debate on the side of the fashionable harm reduction discourse - and that so, while critical of 'science', she remains uncritical of neoliberalism? at this level, in the critical process, we are not merely communicating. We are creating and revising objects that we use to reconstitute communities and participants who remain particular and unique, but who are of some extension and relevance ${ }^{6}$.

In the tradition of cultural-historical activity theory, this middle ground between the universal and the particular - the reconstruction of which defies both nomothetic and idiographic ideas of science - can be discussed in terms of the prototypical, as the practical production of something qualitatively new which is seen to be feasible and relevant under certain historical conditions and which realizes certain human potentials.

The idea of prototypes has come a long way since Vygotsky's experimental-genetic method (Vygotsky, 1980). The leaning toward a modernistic and scientistic essentialism with which some of his followers, in east as in west, survived Stalinism and cold war, even as Marxists, sometimes led to a fetichization of the ideal in the shape of certain local practices which were objectified as prototypes of the features of Humanity which were sought realized. The concreteness of these utopia, their interrelations of the abstract and the concrete, were handled as scientific experiments, with all the hidden assumptions that all other things could be equal and the context could be left in silence. The prototype would be objectified as a technology, as an immutable mobile, numb to the particularities of the subjects it represented.

The contextualizing move that countered this tendency, first with (German and Scandinavian style) Critical Psychology, later with the postmodern, poststructuralist, and situated currents, would mostly, not only point to the ideological contents of specific prototypes, but scrap the idea of a prototype altogether, leaving it behind as a token of the ideology of science.

However, as much as this was meant as a critical and democratic project - and of course, 
connected with the growing social critique of expertise and science in the second half of the $20^{\text {th }}$ century - in terms of empirical methodology, the paradoxical result was sometimes rather elitist. It was as if academic deconstructions of texts, and textual representations of "voices" or "perspectives" of participant subjects, espoused in open-ended qualitative interviews, were quite sufficient to realize critical intentions. Further, it was tacitly assumed that these forms of objectification - incidentally, the ones closest to the institutions of academia itself - were somehow immune to ideology, so that their form-content (Ruben, 1978) need not be scrutinized and it would not be relevant to study the communities they helped constitute. They were seen in purely negative terms, as opening spaces of possibilities and reflection, as deconstructing the given, as emancipating and diversifying etc.; their positivity, on the other hand, could be left to externalities such as the contingencies of academic carieers.

If we now, as I propose, to reclaim those positivities for critical reflection, return to the idea of prototypes, but this time explicitly as contextualized in a social practice that recognizes participants as subjects, and inseperable from a critique of ideology, two impending issues resurface.

First, the issue of the multiple relations between the social practice which is considered to be ,prototypical“", and the objects themselves (the prototypes) with which that prototypical quality is realized (inscribed). This is far from simply a question of the more or less representational qualities of artifacts like texts and images, even when one considers the whole range from raw data to academic publication. It is a question, also, of the ways in which those artifacts (and let us keep in mind that those identifiable with or as research are typically only a few among many) in their capacity as models become relevant to the maintenance or development of practices, i.e. in facilitating certain kinds of focus, in mediating certain simplicities ${ }^{7}$. Moreover, it is about the ways they may indexically define those practices as distinct communities, and about the practical implications of such definitions - that is, how those artifacts, and the distinctions and focuses they facilitate or inforce, are used in forming the activities and the communities to whom they are relevant ${ }^{8}$. This includes, notably, the question of how the thus formed communities may relate in different ways to the participants they (contingently) include as subjects as well as to those they exclude as non-subjects - in a word, of the ideological functioning of the prototype as objectification of subjectivity.

For instance, referring to Wild Learning as prototypical of a certain (or, indeed, uncertain) kind of welfare state social work opens a question of why the "network" of Copenhagen City institutions should be delimited thus", why it should be discussed as the "network of" this one of its institutions; what is gained, inhibited or enhanced by the analysis of policies in the „easily deniable“ form of a ,discourse“ whose authorship is secondary and uncertain.

These questions are of a practical and consequential nature. That is, further, not only part of how that Internet site works, but becomes also the working of research: one thing that a text such as this may do is make some people ask, im- or explicitly: ,participants of the Wild Learning network - is that who we are?" (insofar as they actually read it). Conversely, this kind of questions about the practical workings of discourse and artifacts will not seem far-

7 To paraphrase Hegel's rendering of the general (allgemeinheit) in his Phenomenology (Hegel, 1988), p.72

8 This is equivalent to "framing" in Goffmann's deep sense of not only "seeing or playing as", but "doing as" and "being as" (Goffman, 1986)

9 The idea of a "network", in fact, can be seen as the attempt to ignore the fact that any collectivity is boundered and thus self-defining - thus, the network is the immediate conceptual opposite to the space, with its endless fabric of relations between similar points. 
fetched from the vantage point of those ,participants of the Wild Learning network". In fact, the profane and variable production of categories as fleeting objectifications that work to subjectify and interpellate is a long tradition of a ,cultural pedagogy“ that has taught me some of these ideas. One small example is the use of the word ,wild“, with its connotations of a noble savage and of how excess energy and violations of given norms can be positive resources that characterize social workers and youngsters alike. The hash-girls' internet essays define the girls as just that: a ,hash-smoking girl", but - in sharp contrast to any specialized drug counseling facility - only provisionally and superficially. The category has never been fixed by any expertise, it does not enroll or align any too vital resources, and leaving it behind does not imply leaving the community behind. If those essays are artifacts that objectify prototypical everyday lives of ,hash-smoking girls“, for all practical purposes and to all participants the scope of their relevance is known to be limited and transformable.

The second resurfacing issue is just that of such scopes of relevance. We can begin to engage with this issue once we escape the grip of absolute scientific universality and its negative critical counterparts / mirror-images (multiplicity, complexity, diversity etc.). Discussing the problem of generality as one of the relevance(s) of a prototype leaves open a range of important questions which are otherwise often glossed over.

Thus, the implementation of ideas represented in a prototype is immediately recognized as problematic. It may, but in no way must, take the form of a copying from an industrial blueprint. Even then, both production and use of copies will be obviously different from those of prototypes. It is no surprise, correspondingly, that the relations between Makarenko's Gorkij Colony, his book, its mass production, its Danish translation, and the work of the Copenhagen social worker readers, are very far from understandable through the simple category of identity which underlies much methodological thinking ${ }^{10}$. One is faced with the many mediating questions that still remain even if we assume that it has already been established what are the relevant local dimensions, that is, when we have tentatively made an abstraction, and embarked on the arduous "ascent to the concrete" (Ilyenkov, 1977a; Ilyenkov, 1991).

Further, prototypes are understood to be not just possible, but at least in some ways desirable as well. Their relevance depends on some normative judgement. This not only connects back to the above issue of ideological constitution, but also urges us to reconsider the "social engineering" trope of realizing human potentials as pertaining to the notion of scope of relevance. Humanity is a level of potential generality of relevance as much as it is a set of ideals; it is by the generalizing reference to the humanly possible that an oppressive situation can be criticized. But, since a prototype never fully detaches from the social situation in which it is relevant, it retains the productive and unfinished tensions between the humane and the situated. There is no guarantee against ideological naturalization, of course, but no more is there any intrinsic reason why a prototypical realization of human potentials should be reducable to it.

\section{Scientific publication as prototypical of globalized discourse}

This problem of generality, or scope of relevance is itself "wild" in the sense that its reflection is a never-ending process. The concrete

10 The extreme version of that problem can be represented by Weick's anecdote of the French soldiers who are lost in a snowstorm in the Alps, then find a map which helps them find their way back to the camp - only to be informed that it was a map of the Pyrannées (Weick, 1995). 
forms it takes depend on the communities to which it is relevant - including, of course, those of science itself. Let me conclude, then, with a reflection on the scope of relevance of the scientific objectifications that this text is part of.

The critical analysis I propose of the hashsmoking girls' essays intervenes in Wild Learning and the Copenhagen debates on drug use and social work. But it also intervenes in the ongoing debates on social work and drug use among those who would consider reading the Outlines. And there is a way in which this is itself potentially problematic.

As related to the discipline of social work, this paper connects to an international discussion of what we often take to be global discursive forms such as welfare, social work, normativity, empowerment etc. This is true even of the most situated or poststructuralist analyses. We have a long history (in Denmark and in Europe) of importing 'social work' from America, probably dating back to the very deliberate and determined efforts of the Rockerfeller Foundation after WW $1^{11}$. But that does not imply that "social work" is simply the same in the USA as in Denmark, the United Kingdom, or any other European country.

What if objectifying discursive forms as global means not only reflecting, but thereby actually reproducing neoliberal globalism? What if that which we need to address should be the specifics of the Danish welfare state, at the turn of the millennium, and as part of the EU and the New World Order in a unique way - just as we obviously must address the

11 About this historical reconstruction, see (Bernild, 1999; Bernild, 2003; Buus, 2001; Højrup, 2003a; Højrup, 2003b; Jensen, 2003). The analyses are largely derived from a collective research project on the "Welfare state at a cross-roads". See $w w w . h u m . k u . d k / l o v-$ significantly, though, almost all of this material is in Danish, but it may give some impression of the interdisciplinary project on the history and culture of the Danish welfare state. specifics of Ukraine in the first Soviet years if we are to understand Makarenko?

Currently, it seems to me that we may be in the process of forgetting the specifically Nordic form of welfare state universalism. It is true that ever since World War 2 the human social rights discourse of Beveridge and Marshall have permeated political language. This corresponded in Denmark with an important change. Before the war, Danish welfare was largely organized as state support for cooperative self-help in the social classes, e.g. subsidizing the small farmers' or the workers' health insurance etc. (although these were never, as in Germany, directly related to employment). After the war, all of these organizations were gradually taken over by the state. But universalism, before and after, was never conceived only as the abstract civil right of the naked human being; rather, it was the argument for building a just society through state institutions for all: health system, schools, pensions, kindergartens, nursery schools, institutions for old people - these were not to help the poor who couldn't manage themselves, yet who still had this universal social right, but because this was the way of a modern "human society".

This kind of universalism was probably the result both of strong labour movements and the position of the Nordic countries as frontline states in the cold war. After the Americans withdrew from financially securing Western Europe with the Nixon doctrine, with the subsequent recession, and with the fall of the great industry in Europe, and of course, after the fall of the Berlin Wall, the Nordic welfare states are gradually retreating, and with them, their proponents gradually begin to speak in terms of abstract humanism.

When I adopt, as I do above, the analyses of Philp, Stenson, Rose and other British writers on the theme of social work - or those of Donzelot in France or Cruikshank in America - I need to be just as careful with transfer as when I use Makarenko. This is true of the 
distance in time as well as in space. Philp emphasizes abstract humanism and the relation of society toward the socially excluded; Rose, at the other end of the Thatcher regime (but referring to Deleuze) proclaims the death of the social. Philp is still critical, whereas Rose seems content with description.

When I try to emphasize how humanism may be concretized in social work, not only in the American form where empowerment means self-responsibility, but by the mutuality of reconstituting society and individuals, and when I refuse to accept the death of the social or the retreat from ideology critique to academic discourse analysis - maybe that is not only the result of a certain theoretical approach (which still carries the name 'critical psychology'), but also of the specific needs of a Nordic theorizing of social work in the welfare state.

\section{References}

Althusser, L. (1994). Ideology and Ideological State Apparatuses (Notes Towards an Investigation). In S.Zizek (Ed.), Mapping Ideology (pp. 100-140). London: Verso.

Bernild, O. Oversigt over velfardsstatens udvikling. Arbejdspapir til udviklingsprojektet Livsformer og Velfærdsstat ved en korsvej. [Outline of the development of the welfare state] Københavns Universitet: Institut for Arkæologi og Etnologi. 1999. Ref Type: Unpublished Work

Bernild, O. (2003). The Rise of the Danish Welfare State. Paper for the First Annual International Symposium: Health, Humanity and Culture: Comparative Social Pratices. Serra Retreat House, Malibu California, October 8-9, 2003.

Bowker, G. \& Star, S. L. (1999). Sorting Things Out. Classification and its Consequences. Cambridge, Mass./London: MIT Press.

Brecht, B. (1971). Über Politik auf dem Theater. (1 ed.) Frankfurt/M: Suhrkamp Verlag.
Buus, H. (2001). Sundhedsplejerskeinstitutionens dannelse. En kulturteoretisk og kulturhistorisk analyse af velfardsstatens embedsvark. [The Formation of the Institution of the Health Visitors]. København: Museum Tusculanum.

Cohen, S. (1985). Visions of social control. Cambridge: Polity Press.

Cruikshank, B. (1999). The Will to Empower. Democratic Citizens and Other Subjects. Ithaca \& London.

Dahler-Larsen, P. (2000). Den rituelle refleksionom evaluering i organisationer. [Ritual Reflection. On Evaluation in Organizations]. Odense: Odense Universitetsforlag.

Donzelot, J. (1979). The Policing of Families. Baltimore/London.

Goffman, E. (1961). Asylums. Essays on the Social Situation of Mental Patients and Other Inmates. London: Penguin Press.

Goffman, E. (1986). Frame Analysis. An Essay on the Organization of Experience. Boston: North Eastern University Press.

Hegel, G. W. F. (1988). Phänomenologie des Geistes. Hamburg: Felix Meiner Verlag.

Hofmeister, A. (1998). Zur Kritik des Bildungsbegriffs aus subjektwissenschaftlicher Perspektive. Diskursanalytische Untersuchungen. Hamburg: Argument.

Højrup, T. (2003a). State, Culture and Life-Modes. The Foundations of Life-Mode Analysis. Aldershot, UK: Ashgate.

Højrup, T. (2003b). Two kinds of Welfare State. Welfare State or Welfare Society. Paper for the First Annual International Symposium: Health, Humanity and Culture: Comparative Social Pratices. Serra Retreat House, Malibu California, October 8-9, 2003.

Ilyenkov, E. V. (1977a). Dialectical Logic. Essays on its History and Theory. Moscow: Progress Publishers.

Ilyenkov, E. V. (1977b). The Concept of the Ideal. In E.V.Ilyenkov (Ed.), Problems of Dialectical Materialism (Moscow: Progress Publishers.

Ilyenkov, E. V. (1991). Activity and Knowledge. In E.V.Ilyenkov (Ed.), Filosofiya $i$ Kul'tura [Philosophy and Culture] (Moscow: Politizdat. 
Jensen, U. J. (2003). Health care in the welfare state at a crossroads. Paper for the First Annual International Symposium: Health, Humanity and Culture: Comparative Social Pratices. Serra Retreat House, Malibu California, October 8-9, 2003.

Lave, J. \& Wenger, E. (1991). Situated Learning. Legitimate Peripheral Participation. New York: Cambridge University Press.

Lundqvist, T. \& Ericsson, D. (1999). Ud af hashmisbrug. En ambulant behandlingsmodel. [Out of hash abuse. An outpatient treatment model]. Haslev: Det Schønbergske Forlag.

Makarenko, A. S. (2002). The Road to Life: An Epic of Education. (Vols. I-II) University Press of the Pacific.

Mørck, L. L. (2000). Practice Research and Learning Resources. A joint venture with the initiative 'Wild Learning'. Outlines, 2, 61-84.

Mørck, L. L. (2003). Laring og overskridelse af marginalisering. Studie af unge mand med etnisk minoritetsbaggrund. [Learning and overcoming marginalization. Studies of young men with ethnic minority background]. Aarhus: Psykologisk Institut, Aarhus Universitet.

Nissen, M. (1997). Conditions for User Influence in a Social Development Project. Nordiske Udkast, 25, 45-64.

Nissen, M. (1998a). Brugerindflydelse og handlesammenhange i psykosocialt arbejde. [User Influence and Action Contexts in Social Work]. Aarhus: Skriftserie fra Center for Sundhed, menneske og Kultur. Available at: http://www. psy.ku.dk/mnissen/Text/PHD/INDEX.htm

Nissen, M. (1998b). Ideologies and developments in practical dealings with addiction. In B.K.C.M.M.Fried \& G. Wolf (Eds.), Erkenntnis und Parteilichkeit. Kritische Psychologie als marxistische Subjektwissenschaft (pp. 229240). Berlin/ Hamburg: Argument Sonderband 254. Available at: http://www.psy.ku.dk/mnissen/Text/krips.htm

Nissen, M. (2002a). To Be and Not To Be. The Subjectivity of Drug Taking. Outlines, 4, 39-60.

Nissen, M. (2002b). Wildes Lernen. Nachlese als Vorbereitung. Forum Kritische Psychologie 97-122.
Nissen, M. \& Pedersen, E. H. (2000). The Social Problem Of The Street Level Addict. Presentation to the Conference of NAD Iceland September 2000. Available at: http://www.psy. ku.dk/mnissen/Text/NADweb.html

Nissen, M. 'Wild Learning' - The Beginning of Practice Research about a Project Combining Social Work, Staff Training, and Institutional Reform. Working Papers. 1999a. Aarhus, Network for Non-scholastic Learning, University of Aarhus. Available at: http://www.psy.ku.dk/ mnissen/Text/WildLearning.htm

Nissen, M. (1999b). Subjects, discourse and ideology in social work. In W.et.al.Maiers (Ed.), Challenges to Theoretical Psychology (pp. 286294). North York, Canada: Captus Press.

Nissen, M. (2000). Projekt Gadeb $\phi r n$. Et fors $\phi g$ med dialogisk, bevagelig og lokalkulturel socialpadagogik med de mest udsatte unge. [Project Street Kids. An experiment with dialogical, mobile and local-cultural social pedagogy with the most exposed youth]. Frederikshavn: Dafolo.

Nissen, M. (2004a). Objective Subjectification: The Anti-Method Of Social Work. Mind, Culture \& Activity, 10:4, 332-349.

Nissen, M. (2004b). The Subject of Critique. Forum Kritische Psychologie, 47, 73-98.

Nissen, M. (in press). Mobilizing Street Kids: The Action Contexts of Independence. Paper for the 4th Congress of the International Society for Cultural Research and Activity Theory, june 1998, accepted for proceedings. ISCRAT.

Philp, M. (1979). Notes on the form of knowledge in social work. The Sociological Review, 27, 83-112.

Plant, S. (1999). Writing on Drugs. London: Faber $\&$ Faber.

Rose, N. (1999). Powers of Freedom. Reframing Political Thought. Cambridge: Cambrige University Press.

Ruben, P. (1978). Dialektik und Arbeit der Philosophie.: PRV. Köln: Pahl-Rugenstein Verlag.

Stengers, I. (1999). For en demokratisering av vitenskapene (Sciences et Pouvoirs). Oslo.

Stenson, K. (1993). Social work discourse and the social work interview. Economy \& Society, 22, 42-76. 
Sunesson, S. (1981). När man inte lyckas. Om hinder, vanmakt och oförmåga $i$ socialt arbete. [When one does not succeed. On barriers, powerlessness and incompetence in social work]. Stockholm: Almqvist \& Wiksell.

Valverde, M. (2002). Experience and Truth-Telling: Intoxicated Autobiographies and Ethical Subjectivity. Outlines, 3, 3-18.

Vygotsky, L. S. (1980). Mind in Society. Boston, Mass.: Harvard University Press.

Weick, K. E. (1995). Sensemaking in Organizations. London: Sage.

Willis, P. (2000). The Ethnographic Imagination. Cambridge: Polity. 